\title{
Motivasi Kerja dan Kompetensi Profesional Terhadap Kinerja Perawat di Ruang Rawat Inap Bougenvil dan Seruni Rumah Sakit Umum Daerah Bogor
}

\section{Work Motivation and Professional Competence Towards Nurses Performance in Bougenvil and Seruni Room at Regional Public Hospital Bogor}

\author{
Hafna Rosyita*, Djadjang Aditaruna*, Sugiharto* \\ Universitas Binawan Jakarta \\ Email: miaonahafna@gmail.com, djajang@binawan.ac.id, \\ sugiharto1984@yahoo.com
}

\begin{abstract}
ABSTRAK
Kinerja perawat memberikan pengaruh terhadap mutu pelayanan keperawatan di ruang inap. Banyak faktor yang mempengaruhi kinerja perawat baik yang berasal dari diri sendiri ataupun manajemen rumah sakit. Penelitian ini bertujuan untuk mengetahui tentang pengaruh motivasi kerja dan kompetensi profesional terhadap kinerja perawat di ruang rawat inap Bougenvil dan Seruni RSUD Cibinong Bogor. Penelitian ini merupakan penelitian kuantitaif dengan pendekatan cross sectional study. Metode yang digunakan adalah deskriptif analitik. Teknik pengumpulan data menggunakan wawancara, dan kuesioner. Teknik analisis data diawali dengan menggunakan analisis bivariat, dan chisquare untuk mengetahui pengaruh variable independent terhadap variabel dependen. Hasil penelitian menunjukkan bahwa ada pengaruh positif dari motivasi kerja terhadap kinerja perawat, sedangkan kompetensi profesional tidak memberikan pengaruh yang signifikan terhadap kinerja perawat karena para perawat selalu menyelesaikan tugas dan tanggung jawabnya sesuai dengan standar operasional yang berlaku di RSUD Cibinong. Implikasi dari penelitian ini berorientasi pada peningkatan perhatian rumah sakit terhadap kinerja perawat dari berbagai faktor yang mempengaruhinya. Hasil penelitian juga bisa dijadikan sumber rujukan pimpinan di RSUD Cibinong dalam merancang program peningkatan kualitas kerja perawat.
\end{abstract}

Kata Kunci: Kompetensi Profesional, Kinerja, Motivasi Kerja, Perawat

\section{ABSTRACT}

The performance of nurses has an influence on the quality of nursing services in the inpatient room. Many factors affect the performance of nurses, both from themselves and hospital management. This study aimed to know about the effect of work motivation and professional competence on the performance of nurses in Bougenvil and Seruni inpatient rooms at Cibinong Bogor Hospital. Research used quantitative through cross sectional study approach. The research method used an analytic descriptive. Data collection techniques used interviews, and questionnaires. The data analysis technique started using bivariate analysis and Chi-Square to know the effect of independent variable on dependent variable. The results showed that there was a positive effect of work motivation on nurse performance, while professional competence did not have a significant effect on nurse performance because the nurses always complete their duties and responsibilities in accordance with the applicable operational standards at Cibinong Hospital. The implication of this research that it is oriented towards increasing the hospital's attention to the performance of nurses from the various factors that influence it. The results of the research can also be used as a source of reference for the leadership at Cibinong Hospital in designing a program to improve the quality of work of nurses.

Keywords: Professional Competence, Performance, Work Motivation, Nurse 


\section{PENDAHULUAN}

Rumah sakit harus memberikan pelayanan yang cukup baik dan memuaskan bagi para pasien dan keluarganya. Oleh karena itu, semua sektor yang terlibat seperti dokter, perawat ataupun staf administrasi harus mampu menunjukkan kinerja yang berkualitas. Kinerja setiap orang akan dipengaruhi oleh faktor internal seprti motivasi ataupun kemampuan (kompetensi dari keahlian yang dimiliki). Motivasi menjadi pendorong bagi perawat dalam menyelesaikan tugas dan tanggung jawab serta menyesuaikan diri dengan lingkungan kerja. Motivasi memberikan dorongan melaksanakan tugas sesuai dengan target sehingga kemampuan atau kompetensi yang dimiliki bisa memberikan hasil kerja yang maksimal.

Dalam menjalankan fungsinya, Rumah Sakit harus melaksanakan pelayanan yang berkualitas dan professional dengan tingkat kemampuan para dokter dan perawat ataupun administrasi yang memiliki nilai standar. Salah satu komponen terpenting dalam mencapai kinerja rumah sakit yang baik adalah keberadaan perawat. Artinya dapat dipahami bahwa perawat yang menjalankan tugasnya dengan sangat baik dapat memberikan kepuasaan terhadap layanan pasien (Sulistyo Budi et al., 2020; Alim, Tangdilambi, \& Badwi, 2019). Dengan demikian, perawat dapat dikatakan memiliki kinerja yang baik. Tingkat kerja professional perawat menjadi tuntutan yang mengarah pada kompetensi atau kemampuan kerja yang sesuai dengan standar professional.

Standar professional mencerminkan tingkat kinerja perawat. Tujuan dari standar professional kinerja unutk mengarahkan praktik keperawatan yang aman dan kompeten (Davis, 2014). Perawat memiliki etika kerja professional yang mampu menjaga kompetensi dan kerja sama yang terkait dengan komponen lain di rumah sakit (Lockhart, 2017). Oleh karena itu, rumah sakit memiliki peran yang besar dalam menjaga tingkat kepercayaan dari kelompok perawat sehingga hal ini bisa berdampak para pemberian kinerja para perawat terhadap layanan pasien (Ko, Yu, \& Jeong, 2020).

Layanan pasien yang memuaskan memberikan tingkat kepercayaan kepada para perawat. Hal ini bisa berdampak pada tingkat kepercayaan organisasi dan produktivitas karyawan dalam menyelesaikan tanggung jawab. Seperti dari hasil penelitian yang menyimpulkan bahwa ada korelasi yang signifikan antara kepercayaan organisasi dan produktivitas (Bahrami, Hasanpour, Rajaeepour, Aghahosseni, \& Hodhodineghad, 2012). Perawat yang mengerjakan tugas dan tanggung jawab memiliki tingkat kinerja yang berbeda. Komponen produktivitas berkaitan dengan cara seseorang menghasilkan atau menyelesaikan pekerjaan melalui cara-cara atau prosedur standar kerja yang digunakan 
Hafna Rosyita, Djadjang Aditaruna, Sugiharto : Motivasi Kerja dan Kompetensi Profesional ....

suatu organisasi. Kinerja berpengaruh langsung terhadap atribut individual seperti kemampuan dan pengalaman; dukungan organisasi seperti sumber daya dan teknologi; dan upaya atau kesadaran seseorang untuk bekerja keras terhadap apa yang sedang dilakukan.

Berdasarkan hasil observasi yang telah dilakukan dijelaskan bahwa kondisi produktivitas kerja perawat di RSUD Cibinong mengalami penurunan. Dari hasil analisis dokumen hasil penilaian kinerja perawat menunjukkan bahwa sebanyak 55\% ketidakpuasan pasien dari asuhan keperawatan yang menimbulkan kinerja perawat dinilai harus ditingkatkan kembali. Sedangkan data pelaksanaan tugas perawat yang sesuai SPO hanya $40 \%$, artinya masih ada $60 \%$ yang menyebabkan proses tindakan belum seutuhnya sesuai dengan SPO yang berlaku. Dari data tersebut diketahui bahwa permasalahan yang terjadi di Rumah Sakit Umum Daerah Cibinong dalam pelaksanaan atau implementasi asuhan keperawatan belum sesuai dengan intervensi yang telah dibuat, tindakan keperawatan pun cenderung masih ada yang belum sesuai SPO yang telah dibuat. Dari hasil wawancara dengan kepala perawat yang bertanggung jawab di ruang rawat inap Bougenvil dan Seruni RSUD Cibinong menekankan bahwa keragaman hasil kinerja perawat belum sesuai dengan harapan yang telah ditetapkan oleh rumah sakit. Upaya peningkatan mutu pelayanan keperawatan untuk arah perbaikan selama ini belum optimal, pihak manajemen perlu melakukannya untuk mengatasi penyebab fenomena tersebut diatas dengan terlebih dahulu mengkaji faktor penentu kinerja perawat di Rumah Sakit Umum Daerah Cibinong.

Dari kajian lebih mendalam terkait permasalahan yang muncul, kegiatan wawancara pada 10 orang perawat di Ruang Rawat Inap Bougenvil dan Seruni RSUD Cibinong Bogor disimpulkan bahwa tingkat produktivitas kerja menurun disebabkan karena keinginan atau dorongan mencapai prestasi kerja menurun. Para perawat membutuhkan motivasi untuk meningkatkan produktivitas kerja. Seperti yang diungkapkan oleh Mangkunegara bahwa ada hubungan positif antara motif berprestasi dengan pencapaian hasil kerja. Motif berpretasi dihasilkan karena adanya dorongan dalam diri seseorang untuk melakukan kegiatan atau tugas dengan sebaik-baiknya sehingga mampu mencapai pretasi kerja (kinerja) dengan predikat terpuji (Mangkunegara, 2000). Dari pendapat tersebut diketahui bahwa motivasi menjadi bagian yang terpenting bagi perawat. Selain motivasi, hasil kinerja seorang perawat juga bisa dilihat dari tingkat kompetensi 
professional kerja. Seorang perawat yang memiliki kompetensi kerja profesional biasanya tetap menyelesaikan pekerjaan dengan sangat baik.

Setiap kinerja yang baik terkait dengan perilaku yang ditunjukkan dalam menyelesaikan pekerjaan dan ketekunan mengatasi segala masalah yang dihadapu sehingga mampu mendapatkan penyelesaian masalah dengan tepat, serta kinerja juga dipengaruhi oleh motivasi yang tinggi dalam bekerja. Selain itu, perawat harus memiliki kompetensi yang mumpuni dalam bekerja terkait dengan profesi serta kemampuan komunikasi. Komunikasi yang baik dipengaruhi juga oleh keberhasilan kinerja yang maksimal (Parulian, Siagian, \& Wahyuni, 2014). Jadi, kompetensi perawat dalam berkomunikasi memberikan pengaruh yang baik terhadap lingkungan kerja (Rahman, 2015). Hasil kajian lain menunjukkan bahwa kompetensi dan motivasi bisa memberikan pengaruh terhadap kepuasaan dan kinerja (Deswarta, 2017). Bentuk motivasi yang meningkatkan kinerja perawat di ruang rawat inap RSUD Alimuddin Umar Lampung Barat seperti bentuk insentif, ataupun bonus (Zainaro, Isnainy, Furqoni, \& Wati, 2017). Oleh karena itu, berbagai cara perawat dalam mendorong kinerja bisa berasal dari dalam diri mereka sendiri ataupun orang lain. Identitas professional perawat tidak hanya terlihat dari kompetensi saja, namun cara perawat memimpin pekerjaannya sendiri sebagai bentuk tanggung jawab (Joseph et al., 2020). Perawat perlu lebih kompeten dan berkomitmen pada organisasi mereka. Mengembangkan kompetensi profesional dan komitmen organisasi sangat penting, tetapi tidak mudah (Karami, Farokhzadian, \& Foroughameri, 2017).

Penelitian ini harus dilakukan untuk menyelesaikan permasalahan yang ditimbulkan dari kinerja perawat yang sering menurun dan beberapa kesalahan standar operasional perawat dalam mengerjakan tugas dan tanggung jawabnya. Dari analisis observasi awal menunjukkan bahwa rumah sakit sudah sangat maksimal dalam memberikan dan mendukung kinerja perawat. Hal ini menjadi alasan kuat kenapa penelitian ini dilakukan dengan orientasi faktor internal perawat. Dari paparan tersebut, tujuan penelitian ini adalah mendapatkan informasi mendalam tingkat motivasi dan kompetensi profesional perawat di ruang rawat inap ruang Bougenvil dan Seruni RSUD Cibinong terhadap hasil kinerja perawat. Dengan demikian, hasil penelitian bisa memberikan manfaat kepada pihak manajemen RSUD Cibinong dalam menemunakan cara meningkatkan motivasi dan kompetensi profesional perawat, khusus di ruang rawat inap ruang Bougenvil dan Seruni RSUD Cibinong. 
Hafna Rosyita, Djadjang Aditaruna, Sugiharto : Motivasi Kerja dan Kompetensi Profesional ....

\section{METODE}

Jenis penelitian yang digunakan adalah penelitian kuantitatif dengan pendekatan cross sectional study. Metode penelitian yang digunakan adalah metode deskriptif analitik. Jadi, penelitian ini mencari pengaruh peran motivasi dan kompetensi professional perawat terhadap kinerja di RSUD Cibinong. Penelitian dilakukan di ruang rawat inap Rumah Sakit Umum Daerah Cibinong, Pengambilan data penelitian dilakukan pada Maret sampai Juli 2020. Populasi pada penelitian ini adalah semua perawat yang bertugas diruang rawat inap Seruni dan Bougenvil Rumah Sakit Umum Daerah Cibinong, yaitu sebanyak 73 orang perawat.

Metode pengumpulan data adalah wawancara, dan kuesioner. Proses wawancara dilakukan pada penelitian pendahuluan dalam mengumpulkan data masalah kinerja perawat. Sedangkan kuesioner diberikan kepada seluruh perawat yang bertugas di unit rawat inap Rumah Sakit Umum Daerah Cibinong. Kinerja perawat dilihat dari hasil pembagian kuesioner kepada perawat yang terkait dengan motivasi kerja dan kompetensi professional.

Instrumen motivasi kerja merujuk pada konsep teori dari George dan Jones yang mengacu pada aspek perilaku perawat dalam melaksanakan kerja, tingkat upaya dan ketekunan dalam mengatasi masalah, serta penentuan keinginan sendiri dalam bekerja (Tentama \& Pranungsari, 2016). Sedangkan kompetensi professional dinilai menggunakan konsep teori dari Gibson, dkk yaitu aspek kemampuan intelektual dan fisik (Rahman, 2015). Pertanyaan-pertanyaan pada kuesioner menggunakan skala likert yang menghasilkan data ordinal. Kuesioner diolah dalam bentuk statistik deskriptif. Teknik analisis data diawali dengan menggunakan analisis bivariat, dan chi-square untuk mengetahui pengaruh variable independent terhadap variabel dependen. Analisis dilakukan menggunakan program SPSS serta data diolah dengan bentuk sajian narasi.

\section{HASIL}

Hasil pengolahan dan analisis data menunjukkan bahwa kinerja perawat sudah menunjukkan hasil yang baik. Adapun sajian data sebagai berikut.

Tabel 1. Pengaruh Antara Faktor Perilaku Kerja Dengan Kinerja Perawat

\begin{tabular}{lcccc}
\hline \multirow{2}{*}{ Perilaku Kerja } & \multicolumn{2}{c}{ Kinerja Perawat } & \multirow{2}{*}{ Total } & $\mathrm{P}$ \\
\cline { 2 - 3 } & \multicolumn{2}{c}{ Baik } & Tidak Baik & \\
\hline Tinggi & $64,7 \%$ & $0 \%$ & 0,000 \\
Rendah & $0 \%$ & $35,3 \%$. & \\
\hline
\end{tabular}

Tabel 1 menyimpulkan bahwa partisipan menyadari bahwa perilaku kerja menjadi bagian terpenting dalam menyelesaikan tugas sebagai seorang perawat. Artinya 
bahwa perawat yang memiliki motivasi kerja untuk aspek perilaku kerja dengan nilai persentase tinggi sebesar 64,7 \%, dan rendah yaitu 35,3\%. Untuk analisis data tentang hubungan motivasi kerja pada aspek perilaku kerja dengan kinerja perawat menunjukkan bahwa P-value yang didapat dari uji chi-squere adalah 0,000 atau $>\alpha 0,05$ ( $\mathrm{p}$ value $>$ 0,05), yang berarti ada hubungan antara motivasi kerja dengan kinerja perawat di ruang rawat inap Bougenvil dan Seruni Rumah Sakit Umum Daerah Cibinong dilihat pada konteks perilaku kerja.

Tabel 2. Pengaruh Antara Aspek Tingkat Usaha dan Ketekunan Dengan Kinerja Perawat

\begin{tabular}{lcccc}
\hline Tingkat Usaha dan & \multicolumn{2}{c}{ Kinerja Perawat } & Total & $\mathrm{P}$ \\
\cline { 2 - 3 } \multicolumn{1}{c}{ Ketekunan } & \multicolumn{2}{c}{ Baik } & Tidak Baik & \\
\hline Tinggi & $74,5 \%$, & $0 \%$ & & 0,000 \\
Rendah & $0 \%$ & $25,5 \%$. & & \\
\hline
\end{tabular}

Tabel 2 menyimpulkan bahwa perawat memiliki motivasi yang tinggi dalam upaya dan ketekunan mengatasi masalah yang dihadapi dalam pekerjaan. Hal ini terlihat dari persentase tinggi sebesar 74,5 \%, dan rendah yaitu 25,5\%. Untuk analisis data tentang hubungan motivasi kerja pada aspek tingkat usaha dan ketekunan menyelesaikan masalah dengan kinerja perawat menunjukkan bahwa P-value yang didapat dari uji chisquere adalah 0,000 atau $>\alpha 0,05$ ( $\mathrm{p}$ value $>0,05$ ), yang berarti ada hubungan antara motivasi kerja dengan kinerja perawat.

Tabel 3. Pengaruh Antara Aspek Keinginan Kerja Dengan Kinerja Perawat

\begin{tabular}{|c|c|c|c|c|}
\hline \multirow[t]{2}{*}{ Keinginan Kerja } & \multicolumn{2}{|c|}{ Kinerja Perawat } & \multirow[t]{2}{*}{ Total } & \multirow[t]{2}{*}{$\mathrm{P}$} \\
\hline & Baik & Tidak Baik & & \\
\hline $\begin{array}{l}\text { Tinggi } \\
\text { Rendah }\end{array}$ & $\begin{array}{c}78 \%, \\
0 \%\end{array}$ & $\begin{array}{c}0 \% \\
22 \% .\end{array}$ & & 0,000 \\
\hline
\end{tabular}

Tabel 3 menyimpulkan bahwa perawat memiliki motivasi yang tinggi untuk keinginan bekerja dengan baik sesuai pada standar yang telah ditetapkan oleh rumah sakit. Hal ini terlihat dari persentase tinggi sebesar $78 \%$, dan rendah yaitu $22 \%$. Untuk analisis data tentang hubungan motivasi kerja pada aspek keinginan kerja dengan kinerja perawat menunjukkan bahwa P-value yang didapat dari uji chi-squere adalah 0,000 atau $>\alpha 0,05$ ( $\mathrm{p}$ value $>0,05$ ), yang berarti ada hubungan antara motivasi kerja dengan kinerja perawat.

Tabel 4. Pengaruh Antara Kompetensi Profesional Dengan Kinerja Perawat

\begin{tabular}{|c|c|c|c|c|c|c|}
\hline \multirow{2}{*}{$\begin{array}{l}\text { Kinerja } \\
\text { Perawat }\end{array}$} & \multicolumn{2}{|c|}{ Kemampuan Intelektual } & \multicolumn{2}{|c|}{ Fisik } & \multirow[t]{2}{*}{ Total } & \multirow[t]{2}{*}{$\mathrm{P}$} \\
\hline & Baik & Tidak Baik & Baik & Tidak Baik & & \\
\hline Tinggi & $87,5 \%$ & $0 \%$ & $0 \%$ & $33.3 \%$ & & 0,094 \\
\hline Rendah & $0 \%$ & $12.5 \%$ & $66,7 \%$. & $0 \%$ & & \\
\hline
\end{tabular}


Hafna Rosyita, Djadjang Aditaruna, Sugiharto : Motivasi Kerja dan Kompetensi Profesional ....

Hasil analisis data tentang kemampuan profesional kerja perawat di ruang rawat inap Rumah Sakit Umum Daerah Cibinong sebesar 82,40 \%. Dari hasil pengamatan dan wawancara dapat disimpulkan bahwa mayoritas kemampuan profesinal kerja perawat sudah baik. Sedangkan hasil analisa aspek kemmapuan intelektual menunjukkan kompetensi profesional kerja perawat sebesar 87,5 \% dan telah dinilai memiliki kinerja tinggi, sedangkan perawat yang kompetensi profesional kerja rendah pada aspek fisik memiliki kinerja rendah sebesar 66,7 \%. Pada data wawancara lanjutan disimpulkan bahwa faktor fisik rendah disebabkan karena ketidakteraturan perawat dalam mengelola waktu istirahat. Hasil P-value yang didapat dari uji chi-squere adalah 0,094 atau $>\alpha 0,05$ (p value $>0,05$ ), yang berarti tidak ada hubungan antara kompetensi profesional kerja dengan kinerja perawat di ruang rawat inap Rumah Sakit Umum Daerah Cibinong.

\section{PEMBAHASAN}

Dari pengamatan peneliti berhubungan dengan motivasi kerja di ruang rawat inap Rumah Sakit Umum Daerah Cibinong perlu mendapatkan perhatian dari pimpinan. Dalam analisanya, terdapat hubungan yang signifikan antara motivasi kerja dengan kinerja perawat, artinya perlu ada perhatian khusus dari pemimpin rumah sakit karena dapat mempengaruhi kinerja perawat. Selain itu, perawat juga harus memacu diri mereka sendiri agar terbangun rasa tanggung jawab yang besar dalam menyelesaikan tugas. Hal ini sejalan dengan penelitian terdahulu yang menyimpulkan bahwa ada hubungan positif antara motivasi kerja dengan kinerja perawat.(Zainaro et al., 2017) Hal yang sama diketahui bahwa secara parsial keberadaan kompensasi, kepemimpinan dan motivasi memberikan dampak yang cukup positif terhadap kinerja perawat.(Mulyati \& Rusmiwati, 2020).

Hasil analisis data tersebut sesuai dengan penelitian dari Sukamto dan Rasmun yang menyimpulkan bahwa kompetensi memiliki pengaruh negatif terhadap kinerja perawat di RSUD IA Moeis Samarinda dan RSUD Beriman Balikpapan. Namun, kepuasaan kerja perawat berpengaruh terhadap kinerja perawat (Sukamto \& Rasmun, 2020). Penelitian berbeda tidak sejalan dengan hasil penelitian ini dari Rusvitawati bahwa kompetensi berpengaruh terhadap kinerja karyawan di rumah sakit Sari Mulia Banjarmasin (Rusvitawati, 2016). Kompetensi berpengaruh positif dan signifikan terhadap kinerja pelaksanaan asuhan rawat inap di Rumah Sakit Umum dr. Slamet Garut (Indriani, 2018). Jadi Faktor-faktor yang mempengaruhi proses pengembangan kompetensi profesional dalam keperawatan meluas ke domain pribadi dan ekstra-pribadi. Kompetensi, masalah kontroversial dalam pengaturan perawatan kesehatan, 
mempengaruhi banyak aspek profesi keperawatan, termasuk pendidikan, praktik dan manajemen. Kompetensi profesional kerja yang harus dimiliki oleh perawat banyak sesuai dengan kemampuan dan kebutuhan tempat kerja. Dari penelitian Nasution, dkk disimpulkan bahwa kompetensi fungsi diagnostik, mengelola situasi dan memastikan kualitas tidak terdapat pengaruh positif signifikan terhadap kinerja perawat puskesmas (Nasution, Fahmy, \& Huriani, 2019).

Penelitian ini juga tidak sejalan dengan konsep teori bahwa ketika kemampuan seseorang itu meningkat maka akan meningkat pula kinerja perawat. Bagaimana tidak, ketika perawat memiliki kemampuan yang baik dalam pelaksanaan asuhan keperawatan atau pelaksaanan SPO maka segala sesuatu tindakannya mempunyai dasar yang bagus sehingga tidak ada satu celah pun untuk terjadinya kesalahan sehingga pada akhirnya kinerja bagus dan kepuasan pasien pun tercapai. Jadi, pimpinan dari RSUD Cibinong bisa mengembangkan kompetensi profesional para perawat dengan memperhatikan proses peningkatakan pengetahuan, sikap, dan keterampilan. Walaupun hasil analisis data menunjukkan bahwa kompetensi professional tidak memberikan pengaruh yang besar terhadap kinerja perawat di RSUD Cibinong Bogor.

Dari hasil pengamatan lebih lanjut diketahui bahwa para perawat sebagain besar telah memahami standar operasional bekerja bagi perawat. Padahal ada 6 faktor yang bisa memberikan pangaruh terhadap pengembangan kompetensi kerja perawat adalah pencapaian tingkat pendidikan, sikap profesionalisme, jenis lingkungan kerja perawat, pengalaman kerja, pola berpikir kritis perawat, dan faktor pribadi perawat (Rizanya, Hariyati, \& Handayani, 2018). Meskipun hasil temuan tidak sejalan dengan penelitian lain yang menunjukkan bahwa pendidikan dan penempatan kerja memberikan pengaruh positif terhadap hasil kerja perawat (Nuryadin, Poetra, \& Putri, 2020). Oleh karena itu, iklim kerja yang baik mempengaruhi motivasi perawat dalam bekerja, seperti yang dikaji oleh Veronica (2020) bahwa iklim di lingkungan kerja memberikan pengaruh terhadap hasil kerja perawat.

Hasil analisis data observasi disimpulkan bahwa kinerja perawat menunjukan hal yang positif, hal ini dapat terlihat ketika perawat melakukan tindakan sesuai dengan Standar Prosedur Operasional (SPO) serta dalam pembuatan standar asuhan keperawatan (SAK) dengan baik. Hasil distribusi frekuensi kinerja, yang dikategorikan kinerja baik lebih besar proporsinya. Hal ini menunjukan bahwa kinerja perawat di ruang rawat inap Rumah Sakit Umum Daerah Cibinong sudah cukup baik dan perlu upaya-upaya peningkatan agar lebih baik lagi. Secara umum kinerja baik seseorang sangat ditentukan 
Hafna Rosyita, Djadjang Aditaruna, Sugiharto : Motivasi Kerja dan Kompetensi Profesional ....

oleh berbagai faktor dan situasi dalam pekerjaan, pemahaman seseorang tentang jenis pekerjaan yang dikerjakan turut berkontribusi dalam menentukan keberhasilan kinerja seseorang terhadap suatu pekerjaan. Prestasi kerja yang ditunjukan oleh perawat di ruang rawat inap Rumah Sakit Umum Daerah Cibinong, perlu mendapat tanggapan yang positif dari pihak manajemen untuk lebih memacu produktifitas dan efektifitas pelayanan yang mereka lakukan. Oleh karena itu, konsep pemimpin dan perilaku kerja positif antara atasan dan bawahan perawat harus dibangun dengan baik baik dari segi kreatifitasm kepercayaan, dan penghindaran rasa ketidakpastiaan terhadap hasil kerja (Afsar \& Masood, 2018). Jadi, setiap pemimpin memiliki gaya yang berbeda dalam meningkatkan kinerja karyawan.

Kinerja merupakan hasil kerja yang tercipta oleh seorang perawat dalam melaksanakan pekerjaanya sesuai dengan tugas pokok, fungsi dan tanggung jawabnya yang telah ditetapkan sebelumnya. Kinerja perawat tidak muncul secara tiba-tiba dan tidak dapat berdiri sendiri, tetapi juga ditentukan oleh berbagai faktor yang saling mempengaruhi. Ada banyak sekali faktor yang dapat menentukan kinerja seorang perawat untuk mencapai mutu yang bagus, mutu keperawatan itu sendiri jika dilihat dari standar asuhan keperawatan (SAK) dan standar prosedur operasional (SPO) ditetapkan oleh Departemen Kesehatan minimal $75 \%$ dari target yang telah ditentukan. Mutu keperawatan ini tentunya sangat mempengaruhi terhadap mutu sebuah rumah sakit yang salah satunya dilihat dari bed of rate (BOR).

Mutu rumah sakit salah satunya terlihat dari BOR yang dicapainya, jika target tersebut belum dapat tercapai bidang keperawatan harus terus mengawasi dan mendampingi kegiatan fungsional, sehingga jika ada masalah bisa diselesaikan dengan solusi yang tepat. Dan ketika target tersebut sudah tercapai, manajemen memberikan reward kepada perawat tersebut agar termotivasi dengan baik dan perawat yang lain dapat terpicu untuk meningkatkan kinerjanya ketika ada sejawatnya yang berprestasi. Karena jika tidak begitu, perawat hanya melihat dengan pola pikir yang sederhana misalnya ketika melihat yang rajin/ bagus penghasilannya atau jabatannya sama dengan dirinya yang bekerja biasa-biasa saja maka orang ketiga akan membandingkan dan cenderung mengikuti perawat yang biasa-biasa saja.

\section{SIMPULAN}

Analisa data menunjukan tidak ada hubungan bermakna antara kompetensi profesional dengan kinerja perawat. Jadi, penelitian ini menemukan variabel independen 
tidak ada hubungan yang bermakna dengan variebel dependen, tetapi bila variabel independen tetap menjadi aspek perhatian pimpinan rumah sakit maka kualitas kinerja akan lebih baik lagi. Sedangkan tingkat motivasi kerja memberikan pengaruh yang positif terhadap kinerja perawat. Dengan demikian, kinerja perawat di RSUD Cibinong secara signifikan dipengaruh oleh motivasi kerja. Kompetensi professional tidak memberikan pengaruh yang besar terhadap kualitas kinerja perawat. Hal ini disebabkan karena prosedur pekerjaan yang dilakukan para perawat merujuk pada penggunaan pengetahuan dan kemampuan mereka dalam bekerja dan dilakukan sesuai dengan standar operasional yang berlaku di rumah sakit.

Berdasarakan hasil penelitian, peneliti mengajukan beberapa saran untuk peningkatan mutu pelayanan rumah sakit khususnya pelayanan keperawatan di Rumah Sakit Umum Daerah Cibinong. Hasil penelitian menghasilkan usulan yang bisa dimanfaatkan oleh pimpinan rumah sakit agar tetap memperhatikan semua faktor yang mempengaruhi kualitas kinerja, bukan hanya dari pandangan kelembagaan saja, akan tetapi dari faktor internal perawat itu sendiri. Para pemimpin mampu memaksimalkan motivasi kerja perawat dalam mendukung setiap hasil kerja perawat. Selain itu, peneliti memberikan masukan terhadap manajemen agar dapat mengevaluasi betapa pentingnya motivasi kerja seseorang dalam hal ini perawat, motivasi kerja yang baik dapat mempengaruhi kinerja perawat menjadi lebih baik. Manajemen sebaiknya tetap mempertahankan perawat-perawat yang memiliki motivasi tinggi di rumah sakit umum daerah Cibinong. Pada penelitian ini hanya terbatas pada motivasi dan kemampuan kerja, belum pada bagaimana upaya peningkatan kinerja perawat.

\section{UCAPAN TERIMA KASIH}

Ucapan terima kasih disampaikan kepada semua pihak yang telah membantu penyelesaian penelitian ini dari awal sampai akhir, serta pihak RSUD Cibinong Bogor yang telah memberikan ijin penelitian.

\section{DAFTAR PUSTAKA}

Afsar, B., \& Masood, M. (2018). Transformational Leadership, Creative SelfEfficacy, Trust in Supervisor, Uncertainty Avoidance, and Innovative Work Behavior of Nurses. The Journal of Applied Behavioral Science, 54(1), 3661. https://doi.org/10.1177/0021886317711891

Alim, A., Tangdilambi, N., \& Badwi, A. (2019). Jurnal Kualitas Pelayanan Kesehatan (Studi Analitik Terhadap Pasien Rawat Jalan di RSUD Makassar). Jurnal Manajemen Kesehatan Yayasan RS.Dr. Soetomo, 5(2), 165. 
Hafna Rosyita, Djadjang Aditaruna, Sugiharto : Motivasi Kerja dan Kompetensi Profesional ....

https://doi.org/10.29241/jmk.v5i2.164

Bahrami, S., Hasanpour, M., Rajaeepour, S., Aghahosseni, T., \& Hodhodineghad, N. (2012). The relationship between organizational trust and nurse administrators' productivity in hospitals. Iranian Journal of Nursing and Midwifery Research, 17(6), 451-455. Retrieved from http://www.ncbi.nlm.nih.gov/pubmed/23922588

Davis, C. (2014). The importance of professional standards. Nursing Made

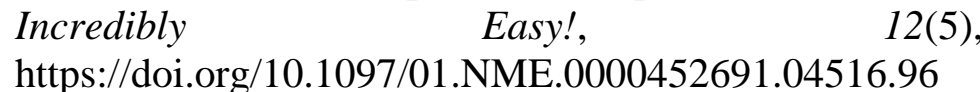

4.

Deswarta. (2017). Pengaruh Kompetensi Dan Motivasi Terhadap Kepuasan Kerja Dan Kinerja Dosen Fakultas Tarbiyah Dan Keguruan Uin Sultan Syarif Kasim Riau. Jurnal Valuta, 3(1), 19-39.

Indriani, I. (2018). Pengaruh Kompetensi Dan Beban Kerja Terhadap Kinerja Pelaksanaan Asuhan Keperawatan Pada Bagian Rawat Inap Rumah Sakit Umum Dr Slamet Garut. Jurnal Wacana Ekonomi, 17(02), 25-32.

Joseph, M. L., Phillips, B. C., Edmonson, C., Godfrey, N., Liebig, D., Luparell, S., \& Weybrew, K. (2020). The Nurse Leader's Role:: A Conduit for Professional Identity Formation and Sustainability. Nurse Leader. https://doi.org/10.1016/j.mnl.2020.10.001

Karami, A., Farokhzadian, J., \& Foroughameri, G. (2017). Nurses’ professional competency and organizational commitment: Is it important for human resource management? PLOS ONE, 12(11). https://doi.org/10.1371/journal.pone.0187863

Ko, Y., Yu, S., \& Jeong, S. H. (2020). Effects of nursing power and organizational trust on nurse's responsiveness and orientation to patient needs. Nursing Open, 7(6), 1807-1814. https://doi.org/10.1002/nop2.567

Lockhart, L. (2017). Our professional ethics. Nursing Made Incredibly Easy, Vol. 15, p. 55. Lippincott Williams and Wilkins. https://doi.org/10.1097/01.NME.0000514217.53757.59

Mangkunegara, A. A. A. P. (2000). Manajemen sumber daya manusia perusahaan. Jakarta: Remaja Rosda Karya.

Mulyati, S., \& Rusmiwati, E. (2020). Pemberian Kompensasi, Motivasi dan Kepemimpinan Terhadap Kinerja. Jurnal Pundi, 04(02), 193-210.

Nasution, R. G. H., Fahmy, R., \& Huriani, E. (2019). Analisis Pengaruh Kompetensi terhadap Kinerja Perawat Puskesmas di Kabupaten XYZ Sumatera Barat. Jurnal Ilmiah Universitas Batanghari Jambi, 19(3), 584589.

Nuryadin, A. A., Poetra, R. P., \& Putri, S. P. (2020). Pengaruh Kesesuaian Penempatan Kerja Dan Kualifikasi Pendidikan Terhadap Kinerja Pegawai Rumah Sakit Bhayangkara Makassar. Jurnal Manajemen Kesehatan Yayasan RS.Dr. Soetomo, 6(2), 209. https://doi.org/10.29241/jmk.v6i2.458

Parulian, H., Siagian, A., \& Wahyuni, E. (2014). The Influence of Competence and Interpersonal Communication on Nurses’ Performance. In Idea Nursing $\begin{array}{llll}\text { Journal (Vol. } & 5 \text { ). } & \text { Retrieved }\end{array}$ http://jurnal.unsyiah.ac.id/INJ/article/view/1621

Rahman, A. W. (2015). Pengaruh Kompetensi dan Lingkungan Kerja Terhadap 
Kinerja Perawat Bagian Rawat Inap Pada Rumah Sakit Umum Daerah (RSUD) Petala Bumi Pekanbaru. Jom FEKON, 2(1), 1-13.

Rizanya, I., Hariyati, R. T. S., \& Handayani, H. (2018). Factors that affect the development of nurses' competencies: a systematic review. Enfermería Clínica, 28(1-A), 154-157.

Rusvitawati, D. (2016). Pengaruh Kompetensi Terhadap Kinerja Karyawan Rumah Sakit Sari Mulia Banjarmasin. AL - ULUM ILMU SOSIAL DAN HUMANIORA, 2(3), 299-311.

Schermerhorn, J. R. (2010). Organizational Behavior 11th Edition. New York: Wiley.

Sukamto, E., \& Rasmun. (2020). Kontribusi Kompetensi Dan Kepuasan Kerja Serta Implikasinya Terhadap Kinerja Perawat Rumah Sakit Umum Daerah di Samarinda dan Balikpapan. Jurnal Media Kesehatan, 13(1), 01-08.

Sulistyo Budi, B., Margawati, A., Agushybana, F., Promosi, M., Fkm, K., Diponegoro, U., ... Tengah, P. J. (2020). Pengaruh Kehadiran dan Kualitas Pelayanan Posyandu Landia Terhadap Status Kesehatan Lansia. In JKM (Jurnal Kesehatan Masyarakat) Cendekia Utama (Vol. 7). https://doi.org/10.31596/JKM.V7I2.497

Tentama, F., \& Pranungsari, D. (2016). The Roles of Teachers' Work Motivation and Teachers' Job Satisfaction in the Organizational Commitment in Extraordinary Schools. International Journal of Evaluation and Research in Education (IJERE), 5(1), $39 \sim 45$.

Veronica, R. (2020). Analisis Faktor Yang Mempengaruhi Loyalitas Perawat Di Rumah Sakit Tugu Ibu Depok. Jurnal Manajemen Kesehatan Yayasan RS.Dr. Soetomo, 6(2), 192. https://doi.org/10.29241/jmk.v6i2.453

Zainaro, M. A., Isnainy, U. C. A. S., Furqoni, P. D., \& Wati, K. (2017). Pengaruh Motivasi Kerja Terhadap Kinerja Perawat Pelaksana Di Ruang Rawat Inap Rumah Sakit Umum Daerah Alimuddin Umar Kabupaten Lampung Barat TAHUN 2017. Jurnal Kesehatan Holistik (The Journal of Holistic Healthcare), 11(4), 209-215.

\begin{tabular}{|l|l|}
\hline Submission & 18 Januari 2021 \\
\hline Review & 19 Januari -24 Maret 2021 \\
\hline Accepted & 25 Maret 2021 \\
\hline Publish & 12 April 2021 \\
\hline DOI & 10.29241/jmk.v7i1.599 \\
\hline Sinta Level & Tiga (3) Nasional Akreditasi \\
\hline
\end{tabular}

